\title{
肺癌培養細胞株(HLC-1)の産生するCEAの 免疫化学的解析
}

\author{
Isolation, Immunological Characterization and Chemical \\ Analysis of CEA Found in a Lung Cancer Cell Line, HLC-1
}

相良憲幸

要旨：ヒト肺癌培養細胞 (HLC-1) の産生するCEA活性物質を分離, 精製し, その抗原解析を行 つた. 我々の精製したHLC-1由来のCEA (HLC-1(CEA)) は, CEA関連抗原のNCA-1, NCA-2とは異なるが, 大腸癌由来CEAとは識別できなかった。しかし，アミノ酸分析， 糖分析や分子量の点で, 従来のCEAとは若干の差異を示しており, 肺癌特異性CEAの存 在の可能性を示唆している.

〔肺癌 25(4)：513～521，1985〕

Key words : Carcinoembryonic antigen, HLC-1, PAGE.

\section{I . まえがき}

肺癌由来のヒト癌細胞株HLC-1は1976年赤 木ら1により carcinoembryonic antigen(以下 CEA と略す)産生細胞株として，すでに報告さ れている。そしてこのHLC-1が高濃度にCEAを 産生していることをCEA-RIA assayや蛍光抗 体法などで渡辺ら ${ }^{2)}$ は証明している。

このCEAは1965年Gold \& Freedmanにより 大腸癌組織に存在する腫瘍特異抗原として報告 されたが，その後多くの追試により内肧葉性腫 瘍のみならず外肧葉性腫瘍にも検出されること, さらには正常組織である肺, 脾, あるいは糞便, 胎便にまで一部交叉する物質の存在が示される にいたり, Goldらにより指摘された大腸癌特異 性は疑問視されている。その他CEAとこれら正 常組織に存在するCEA類似物質との異同につ いては, Burtin() von Kleist, ${ }^{6)}$ 松岡ら ${ }^{7)}$ 免疫的

近畿大学医学部第 1 外科
解析の報告があり, CEA特異抗原決定基と CEA と交叉反応するCEA関連抗原決定基に区別さ れている。この様に, 大腸癌とそれ以外の癌組 織や正常組織に存在するCEAまたはCEA類似 物質を識別しうる抗CEA抗体の作成がCEA研 究の鍵をにぎる重要な問題であるが, 細胞融合 技術を用いた抗CEA monoclonal 抗体による解 析が試みられているものの現在の所, 膵癌に特 異性の高いCA 19-98) な゙未だ僅かで十分とい えない。

しかし，臨床的には癌の補助診断および術後 再発, 肝転移の有無の推定に有用であるとして conventional抗CEA抗体を用いたRIA ${ }^{9)} \mathrm{EIA}^{10)}$ による血中CEA值の测定が定着している.

さらに, 異なる臓器の腫瘍別差異を示すCEA の存在の可能性を検索するにも, ヒト大腸癌肝 転移巣以外に抽出材料として大量にえられる適 切なものがないため, 免疫組織学的検討を加之 た報告 ${ }^{11), 12)}$ はあっても，腫瘍特異抗原の精製分 
析を行った報告はなかった。

著者らは種々のヒト癌培養細胞株の中で, そ の培養液中に多量のCEA活性物質を産生して いるヒト肺癌培養細胞株 (HLC-1)を材料とし て肺癌組織由来のCEAの分離, 精製を試み, 併 せて大腸癌由来のCEA，あるいは，いわゆる $\mathrm{CEA}$ 関連物質との比較検討を行い報告してき た (13) 15) 今回, 更に我々の精製したHLC-1由来 CEAの糖組成についても検討を加えた。

\section{II. 実験材料と方法}

\section{1)癌細胞株の培養}

前報と同様に, 七ト肺癌患者胸水中の腺癌細 胞より樹立したHLC-1を用い，10\%牛胎児血清 $(\mathrm{FCS})$ および $10 \mu \mathrm{g} / \mathrm{ml}$ の gentamycinを加之た RPMI\# 1640培養液中で, 培養後3～5日目の培 養上清中に約 $1000 \mathrm{ng} / \mathrm{ml}$ のCEA活性物質が含ま れる2)ことから, 継代培養後3日目の培養上清を 実験材料として用いた。

\section{2)培養上清中のCEAのゲル濾過法による分離}

分子篩法によるCEAの精製のためBio-Rad社 のBio Gel A-0.5mカラム $(2.6 \mathrm{~cm} \times 90 \mathrm{~cm})$ を用 いて $10^{4} \sim 5 \times 10^{5}$ のsizeを, 更にBio Gel A- $1.5 \mathrm{~m}$ カラム $(2.6 \mathrm{~cm} \times 90 \mathrm{~cm})$ を用いて $10^{4} \sim 1.5 \times 10^{6}$ の sizeを分画し, 更にPharmacia Fine Chemicals 社の Sephacryl S-200カラム 1.6 $\mathrm{cm} \times 85 \mathrm{~cm})$ を用いて $5 \times 10^{3} \sim 2.5 \times 10^{5}$ の sizeを, Sephacryl S-300カラム $(1.6 \mathrm{~cm} \times 85 \mathrm{~cm})$ を用い て $10^{4} \sim 1.5 \times 10^{6}$ のsizeを分画し, Hansenらの方 法に従いCEAロシュキットを用いRIA法によ クCEA活性を含む分画を集めた。

3) 抗HLC-I (CEA) 抗血清の作成

抗HLC-1 (CEA) 抗血清の作成はゲル濾過法 で精製したCEA活性分画Bf Sephacryl S-300 $10 \mathrm{mg}$ を前報 ${ }^{16)}$ に従い, 雑系白色モルモットを用 いDifco社のFreund's complete adjuvantと共 に2週間々隔で2回免度し，2４週後追加免疫と して更に抗原液10mgのみを皮下注射した。この 1週間後に全採血し，これをモルモット抗Bf S300抗血清と名付けた。 この抗血清に含まれる FCSに対する抗体活性を不溶化FCSで吸収操 作した後に得られたものを抗HLC-1(CEA) 抗
血清と名付けた。

4)ゲル内沈降反応

前報で述べた様にHLC-1由来のCEAに対す る抗血清を用いOuchterlony法により1\%寒天 ゲル内で抗原濃度 $30 \mathrm{mg} / \mathrm{ml}$ で抗原解析を行っ た.

5) アフィニティークロマトの作成法

Avrameasら ${ }^{17)}$ の方法に準じて，0.1M酢酸緩 衝液 $\mathrm{pH} 4.9$ で透析した FCS 蛋白抗原に $2.5 \mathrm{M}$ glutaraldehydeを加えてゲル化したものを 0.15 $\mathrm{M} \mathrm{Na}_{2} \mathrm{HPO}_{4}-0.15 \mathrm{M} \mathrm{NaCl}$ で繰返し洗浄し, FCS不溶化抗原とした。

6) 分子量測定のための高速液体クロマトグラ フィー(以下HPLCと略す)

日本分光Trirotor IIIを用いてShodex $\mathrm{OH}$ Pak 0-804カラム $(8 \mathrm{~mm} \times 500 \mathrm{~mm})$ にて, flow rate $0.5 \mathrm{ml} / \mathrm{min}$. pressure $7 \mathrm{~kg} / \mathrm{cm}^{2}$ の条件で, 完全に脱気した蒸留水にて溶出を行った. 分子 量測定の標準にはPharmacia Fine Chemicals 社のGel Filtration Calibration kitおよび我々 の精製したヒトIgG myeloma蛋白を用いた。

7)Disc法によるPolyacrylamide gel electrophoresis (以下PAGEと略す)

PAGE は Davis ら ${ }^{18)}$ 方法に準じて $5 \%$ polyacrylamide gel を用いて, 初めの30分は各 tubeあたり $1 \mathrm{~mA}$ で, 以後 $4 \mathrm{~mA} て ゙ 3$ 時間通電した。

8) Agarose isoelectrofocusing electrophoresisに よるp|の測定

$1 \%$ agarose IEF(Pharmacia Fine Chemicals社)に両性担体として pharmalyte pH 4-6.5 および pH 3-10(Pharmacia Fine Chemicals社)を用いた。陽極液は $0.05 \mathrm{M} \mathrm{H}_{2}$ $\mathrm{SO}_{4}$, 陰極液は $1 \mathrm{M} \mathrm{NaOH}$ を用い15W90分の通 電を行い, pI markerにはIEF Calibration kit (Pharmacia Fine Chemicals 社)pI 2.5-6.5を 用いた。

\section{9)アミノ酸分析法}

Tryptophan, cystine以外のアミノ酸は精製 $\mathrm{CEA}$ を $6 \mathrm{~N} \mathrm{HCl}, 110^{\circ} \mathrm{C}, 24$ 時間加水分解後, HPLCにて分析し, tryptophanは $\mathrm{Ba}(\mathrm{OH})_{2}$ によ り $110^{\circ} \mathrm{C}, 12$ 時間加水分解し, HPLC にて分析 した。またcystineは過ギ酸々化法で行った。 
Fig. 1 Elution pattern of Bio Gel A-0.5m peak/I with Bio Gel A-1.5m column.

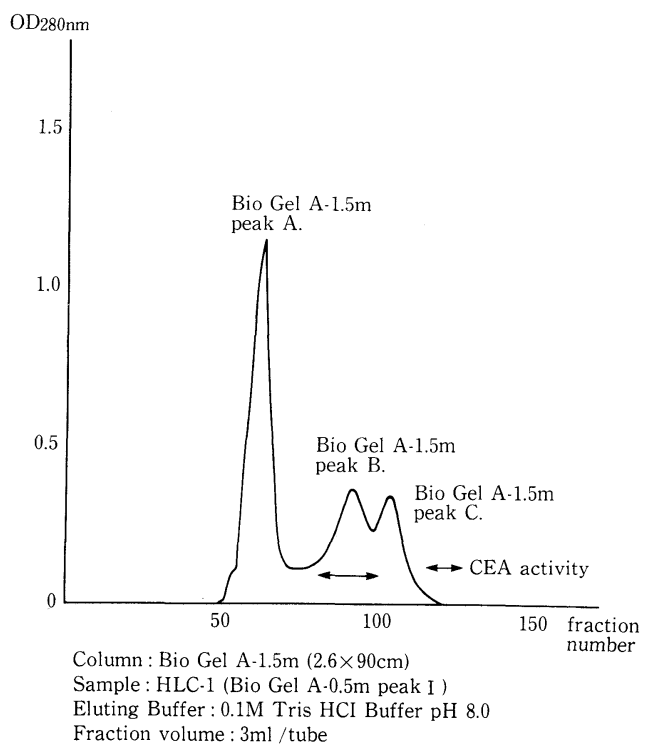

\section{0)糖分析法}

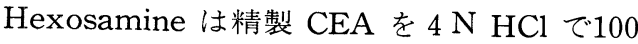
${ }^{\circ} \mathrm{C}, 6$ 時間加水分解し， HPLCにて分析した。中 性糖は精製 CEA $2 \mathrm{M}$ trifluoroacetic acidで $100^{\circ} \mathrm{C}, 6$ 時間加水分解し, HPLCで分析した。 シアル酸は精製CEAをneuraminidase, aldorase で処理した後HPLCで分析した。

\section{III. 実験結果}

1)ゲル濾過法によるCEA分画

HLC-1の培養上清より細胞およびその残渣 の除去を目的として, KUBOTA KR-180にて, $12000 \mathrm{~g}, 30$ 分, $4{ }^{\circ} \mathrm{C}$ で遠沈した上清を脱イオン 水で十分に透析後, 凍結乾燥してHLC-1乾燥粉 末(HLC-1 powder と略す) を得た。このHLC-1 powderを $100 \mathrm{mg} / \mathrm{ml}$ の濃度に蒸留水にて溶解, その $2 \mathrm{ml}$ Bio Gel A-0.5mカラムにて0.1M Tris-HCl緩衝液pH8.0でゲル濾過を行い, 各分 画のCEA活性をZ-ゲル法の直接法にて測定, CEA活性分画Bio Gel A-0.5m peak I を得た。 この分画はゲル濾過法による測定にて $25 \times 10^{4}$ daltonの分子量をもつと推定した。この分画を 凍結乾燥後, 蒸留水に溶解し, $40 \mathrm{mg} / \mathrm{ml}$ の濃度
Fig. 2. Elution pattern of Bio Gel A-1.5m peak/B with Sephacryl S-200 column.

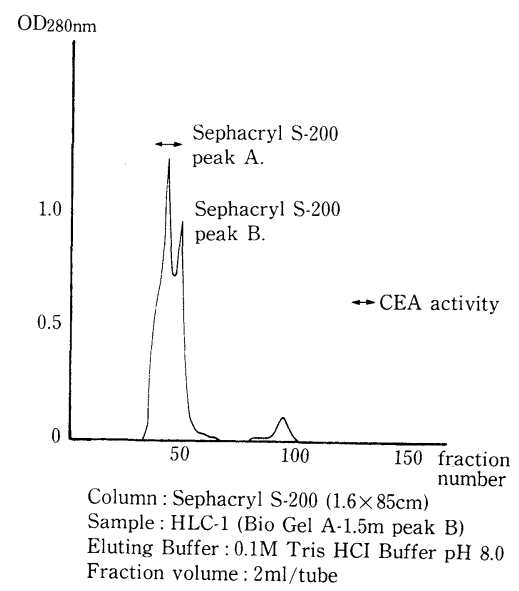

Elution pattern of Sephacryl S-200 peak/A with Sephacryl S-300 column.

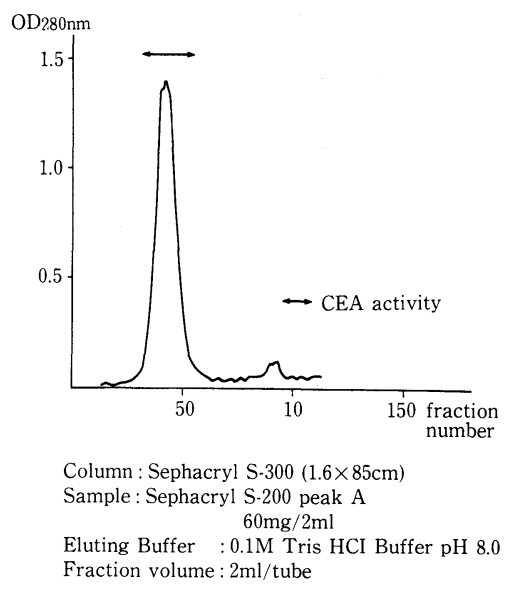

とし，その3mlを更にBio Gel A-1.5mカラムに てゲル濾過を行い, Fig.1に示す溶出曲線を得 た.そのCEA活性を測定するとA，C分画に比 し有意にB分画に高值を認めた。このCEA活性 の高い分画Bio Gel A-1.5m peak BへのA, C 分画の混入を除去するためにSephacryl S-200 カラムにてA分画の, Sephacryl S-300カラムに てC分画の混入を除去し, CEA活性分画Bf S300 と名付けたものを得た(Fig.2).

2) CEA 活性を示す分画の分子量の測定 このBf S-300はShodex OH-Pak 0-804カラ ムを用いflow rate $0.5 \mathrm{ml} / \mathrm{min}$. pressure $7 \mathrm{~kg}$ / 
Fig. 3. Molecular weight calibration of Bf S-300 with HPLC.

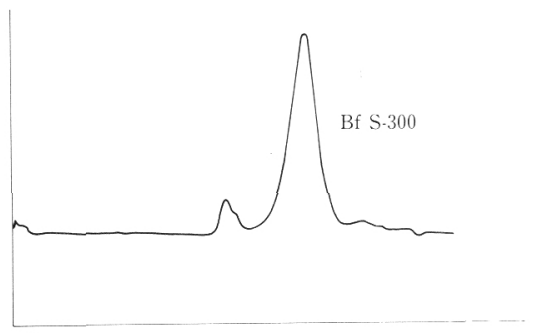

High-Pressure Liquid Chromatography

Fig. 4-A Antigen analysis with guinea pig anti-Bf S-300 antiserum.

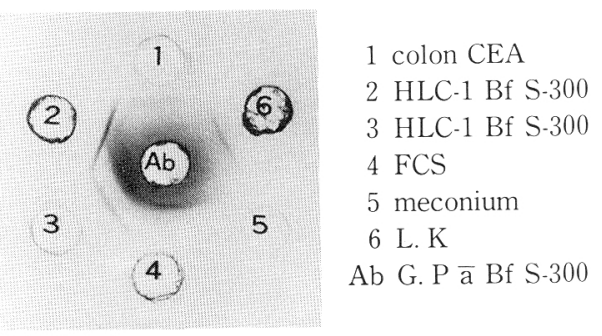

Fig. 4-B Antigen analysis with guinea pig anti-Bf S-300 adsorbed by insol. FCS.

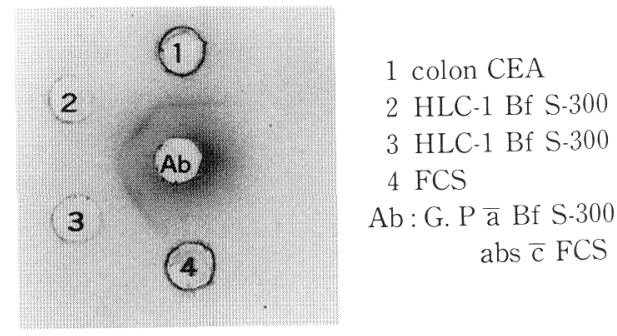

$\mathrm{cm}^{2}$ でTrirotor IIIによるHPLCを，脱気した蒸 留水を用いて行い，標準物質から推定すると Fig.3に示す如く約 $27 \times 10^{4}$ daltonの均一な分画 であることが確認された。

3)ゲル内沈降反応によるBf S-300分画の抗原 解析

モルモット抗Bf S-300抗血清を用いてゲル内 沈降反応を行うとFig.4-Aに示す如くBf S-300 は大腸癌肝転移巣由来 CEA と完全に融合する 沈降線を示した。また培盖液中に $10 \%$ を含む FCS由来の同様な分子量の分画とも反応する
Fig. 5. CEA activity of the 5\% PAGE slices.

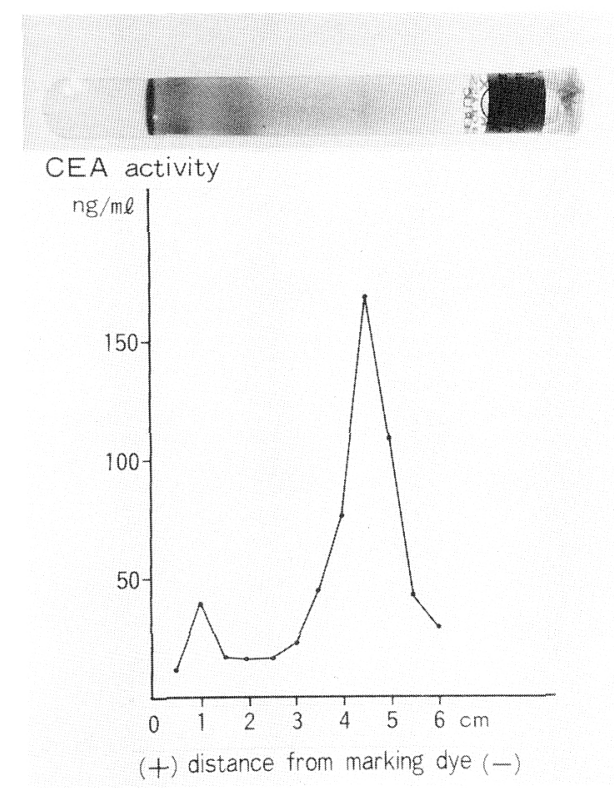

ことがわかった。しかし一般にCEA関連抗原を 多く含むとされる胎便とは全く沈降線を形成し なかった。そこで，FCSと反応する抗体活性を 除去するため，モルモット抗Bf S-300抗血清を FCS不溶化抗原アフィ二ィティークロマト法で吸 収操作を行い，Fig.4-Bに示すようにFCSとは ゲル内沈降法で反応しないモルモット抗HLC1 (CEA) 抗血清を得た。

4)BfS-300分画からのFCS分画の除去と, 兴の 組成の検討

Bf S-300分画は前述の如くFCS成分を含むU とが明らかになったので，Disc法による5\% PAGEを行い，その後Braatz ${ }^{19)} ら の$ 方法に準じ て5mm間隔に細切し, CEA活性分画のみを回収 濃縮して $\mathrm{pI}$ の測定，アミノ酸分析および糖分析 を行った(Fig.5)。その結果Agarose-IEF法にて pI4.4 と推定された (Fig.6)。この精製分画HLC 1(CEA) はPAS染色による糖染色。Coomasie Brilliant Blueによる蛋白染色で同じ一本の bandとして染色され糖蛋白であることを示し ている。

5)アミノ酸, 糖組成の分析 
Fig. 6.

pI of the HLC-1 (CEA) by Agarose-IEF method.

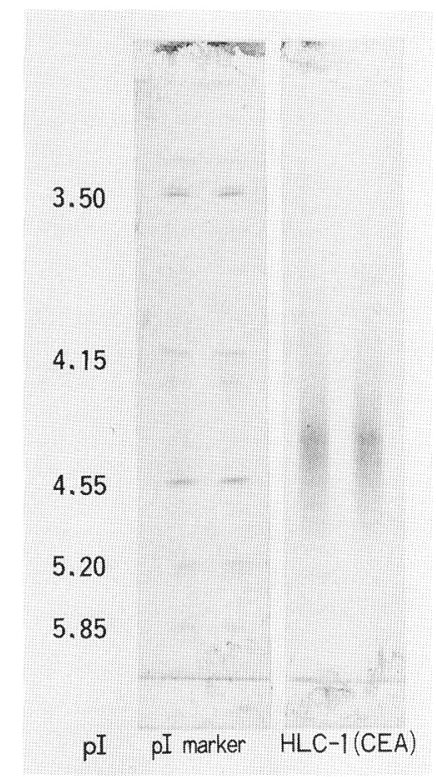

HLC-1細胞由来のCEA分子のアミノ酸組成 と糖組成を分析すると，アミ>酸組成では glutamic acidが13.6\%, aspartic acidが10.6\% と多かったが, methionineの含量は極めて少な かった。

またtrypotophanは全く含まれていなかった。 アミノ酸組成からみると従来の大腸癌由来の CEAおよびCEA関連抗原のNFA-1,20) NFA-2 $2^{21)}$ と酷似していた(Table 1)。糖組成ではN acetylglucosamineが最も多く, Fucoseは従来 のCEAに比べると含量が少なかった。またシア 儿酸は検出することができなかったが, その他 にxylose, rhamnose, glucoseを含むことが従来 の報告ではみられない点は注目される(Table 2).

\section{IV. 考察}

ヒト肺腺癌由来の細胞株 HLC-1がCEAを産 生子ることが, 従来から用いられているCEA測 定Kitで明らかにされ, 著者らは, このHLC-1の産 生するCEAと大腸癌由来のCEAおよびCEA測定 Kitでは識別不可能とされている CEA 関連抗原 $\mathrm{NCA}-2{ }^{22)} \mathrm{NFA}-1^{20)} \mathrm{NFA}-2^{21)}$ との異同を, 免疫化 学的に明らかにすることを試みた。CEAの分離, 精 製はGoldらの報告以後, 大腸癌の肝転移巣を材
Table 1. Amino acid composition of HLC-1 (CEA)

\begin{tabular}{lllr}
\hline arginine & $4.9 \%$ & alanine & $5.6 \%$ \\
lysine & 7.9 & glycine & 4.0 \\
histidine & 3.4 & proline & 5.6 \\
phenylalanine & 5.4 & glutamic acid & 13.6 \\
tyrosine & 3.8 & serine & 5.4 \\
leucine & 9.7 & threonine & 5.5 \\
isoleucine & 3.4 & aspartic acid & 10.6 \\
methionine & 1.0 & tryptophan & 0.0 \\
valine & 6.9 & cystine & 3.3 \\
\hline
\end{tabular}

cystine : performic acid oxidation method

Table 2. Monosaccharide analysis of HLC-1 (CEA)

\begin{tabular}{lc} 
& content $(\%)$ \\
\hline fucose & 3.4 \\
mannose & 23.1 \\
galactose & 23.1 \\
rhamnose & 3.7 \\
xylose & 4.1 \\
glucose & 11.0 \\
sialic acid & 0.0 \\
N-acetyl D-glucosamine & 27.2 \\
N-acetyl D-galactosamine & 4.4 \\
\hline
\end{tabular}

料としたものが多く，種々の精製操作が試みら れたにもかかわらず，標品により電気泳動上， 分子量, 糖含量の点で不均一性が著しい。大腸 癌以外の癌組織に含まれる CEA 活性物質が 大腸癌の CEA と全く同一物質であるか否か は, 免疫組織学的手法による抗 CEA 抗血清 の大腸癌以外の癌組織との反応の相対的な差 から類推しているに過ぎない。著者はHLC-1細 胞培養上清より, 分子篩法により均一な分子 sizeのCEA活性物質を分離した。その結果, HPLCで分子量27万daltonの分画にCEAが含 まれることが明らかになった。これは従来の大 腸癌由来のCEA分子量が20万dalton前後であ るのと比較すると, やや大きいが松岡らも樹立 癌細胞QG-56(肺癌由来), CCK-81 (結晹癌由来)で 同じく従来の報告より大きな分子量であったと している。これは従来の分子量決定が殆んどSDS- 
PAGEによるものであることからSDS処理によ り分子の高次構造の変化が起こることや, 時に はSDSにより小さいfragmentに切れる可能性 も報告されていること蝶から真のCEA分子 sizeを示さない可能性も考えられる。

次いで渡辺らの報告 ${ }^{16)}$ に従い，モルモットを 免疫動物として用い，この分子量27万の分画を 抗原として抗血清を作成し反応性をゲル内沈降 反応で検討すると正常組織で吸収しなくても CEA関連抗原を含むとされる胎便とは全く反 応しないが, 大腸癌肝転移組織由来のCEAと完 全に融合する沈降線を示し HLC-1細胞からの CEA活性物質は大腸癌由来のCEA と近似して いることを示した。しかしFCS中に含まれる分 画と一部交叉を示すことすら牛胎児血清中に分 子sizeの類似した物質が含まれており，このBf S-300分画中に混入していることが考えられる. そこですでに前報で報告した様に，モルモット抗 Bf S-300抗血清中に含まれる抗FCS抗体を不容 化FCS抗原により除去して得られたモルモット抗 HLC-1 (CEA) 抗血清を用い, ヒト大腸癌組織, 肺 癌組織, 正常肺, 大腸組織との反応性を peroxidase標識間接酵素抗体法にて検討した。

その結果モルモット抗HLC-1 (CEA) 抗血清 は, 免疫組織学的方法では癌組織に特異的で, 正常組織とは反応しないことが示されたが，肺 癌に特異的ではなく, 大腸癌組織とも同程度反 応することが明らかになった。

今後この抗血清を用い, より高感度のRIA, EIAによる抗血清の特異性やCEA関連抗原と の交叉の有無を検討する必要がある.

次にHLC-1細胞より分子篩法で分離した CEA活性物質より FCS分画を除去する目的で5 \%PAGEにて, 強くCEA活性を示す分画のみを 単離回収し，その分画のアミノ酸組成を報告さ れている大腸癌由来 CEA と比較すると, methionine含量が極めて少なく, glutamic acid, aspartic acidが多く含まれる点は大腸癌 由来のCEAと極めて類似していることが明ら かになった。

また糖組成に関しても $\mathrm{N}$-acetylglucosamine が多く, N-acetylgalactosamineが少ない点や, galactose, mannose, fucoseを含む点などは大 腸癌由来のCEAと類似している。しかし, 従来 の報告では未決定とされていた tryptophanは 全く含まず，しかもシアル酸も検出されなかっ たことや, rhamnose, xylose, glucoseを含むこ となど相違が認められた。これらの相違点が肺 癌と大腸癌の化学的組成の違いとして一般的に 認められるのかは明らかではないが他の肺癌材 料についても再検討する必要がある.

いづれにしてもこの違いを認識する抗血清を 得ることは出来なかった.

Monoclonal 抗 CEA 抗体を用いた研究報 告25),26)でも，なお大腸癌と肺癌を識別出来る抗 血清は未だ得られていないことや, CEAとCEA 関連抗原とを完全に識別する抗血清すら未だな いことから，CEA自体が癌特異抗原であること に疑問を持つ研究者もいる。

これまでの報告からCEAは癌特異抗原とい うより癌附随抗原と考之るべきで, NCA-2, NFA-2など正常組織に存在するものが, 癌化に 伴いその産生量が増加したり，化学的修飾を受 けるものと考えられる。

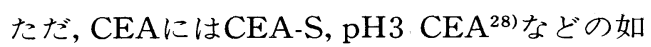
く物理化学的に均一な性状を示すものも報告さ れており, 今回のPAGEで精製したHLC-1細胞 のCEA は, これらのものと同様にCEAの subfractionの一つと考之られる可能性もある が，そのために今後アミノ酸配列を検討し，現 在までのCEA との相違を追求する必要がある.

最近, 松岡ら ${ }^{29}$ はHLC-1細胞を含む5種のヒト 樹立癌細胞には全てCEA活性と NCA-2活性の 両方の抗原を産生しているとCEA, NCA-2特異 抗血清を用いたRIAで測定し区別しているが, 培盖上清に含まれるFCS中のCEA類似物質と の区別も必要と考えられる.

我々の成績は一つの細胞がCEA と NCA-2を 産生しているのではなく, 癌細胞株はFCS成分を 除去することにより NCAとは異なるCEAを産 生することが明らかになり, 今後, 他の癌細胞 株についてもCEAの分離, 精製をし, 従来報告 されているCEAとの差異に関して検討し, 肺癌 の特異抗原決定基を追求することによって得ら 
れる抗血清を用いることにより臨床診断学的価 值が高められるものと考えられる。

稿を終えるにあたり，本研究に御指導と御校閲を賜つ た近畿大学陣内伝之助教授ならびに安富正幸教授に深謝 すると共に，直接御指導を頂いた大阪大学医療短期大学 渡辺信一郎助教授，および糖分析に協力下さった近畿大
学薬学部本田進教授に感謝いたします。

な㧍本研究の一部は文部省科学研究助成金（課題番号 58770911)，厚生省がん研究助成金 (草間班, 梶谷班)に よった。

また, 本研究の要旨は, 第40回(札幌), 第41回(大阪) の日本癌学会総会において発表した。
1) Akagi, T., Kimoto, T.: Esterblishment and characteristics of human lung adenocarcinoma cell line, GANN, 67, 483-492, 1976.

2）渡辺信一郎, 鬼沢三郎, 山村雄一, 他 : 七上癌 培養細胞株のCEA産生の研究, 医学のあゆみ, 97, 398-400, 1976.

3) Gold, P., Freedman, S.O. : Demonstration of tumor specific Antigens in human colonic carcinoma by immunological tolerance and absorption techniques, J.Exp. Med., 121, 439462, 1965.

4) Gold, P., Freedman, S.O. : Specific Carcinoembrynic Antigens of the human digestive system, J.Exp. Med., 122, 467-481, 1965.

5) Burtin, P., Quan, P.C., Sabine, M.C.: Nonspecific cross reacting antigen as a marker for human polymorphs, macrophages and monocytes, Nature, 255, 714-716, 1975.

6) von Kleist, S., Chavanel, G., Burtin, P.: Identification of a normal antigen that crossreacts with carcinoembryonic antigen, Proc. Natl. Acad. Sci. USA, 69, 2492-2494, 1972.

7) Matsuoka, Y., Hara, M.,Kitagawa, M. et al. : Presence of antigen related to the Carcinoembryonic Antigen in feces of normal adults, GANN, 64, 203-206, 1973.

8) Koprowski, H., Steplewski, Z., Michell, et al : Colorectal carcinoma antigens detected by hybridoma antibodies, Somat. Cell Genet.,5, 957-972, 1974.

9) Hansen, H.J., Snyder, J.J., Miller, E. et al : Carcinoembryonic Antigen(CEA) Assay. A Laboratory adjunct in the diagnosis and management of cancer, Human. Pathol., 5,
139-147, 1974.

10）北村元仕, 伊藤寿美子, 飯森糸子, 他：EIAに よる血清CEAの正常值, 医学のあゆみ, 112, 519 $-521,1980$.

11) Gold, P., Gold, M., Freedman, S.O. : Cellular location of Carcinoembryonic Antigen of the human digestive system, Cancer Res.,28, 1331 $-1334,1968$.

12) Sehested, M., Hirsch, F.R., Hou-Jenoken, K. : Immunoperoxidase staining for Carcinoembryonic Antigen in small cell carcinoma of lung, Eur. J.Cancer. Clin. Oncol, 17, 1125-11 31, 1981.

13）相良憲幸, 渡辺信一郎, 安富正幸, 他: 肺癌由 来CEAの抽出, 精製に関する研究, 第40回日本 癌学会総会記事, 987, 1981.

14）相良憲幸, 福原 毅, 安富正幸, 他：肺癌由 来CEAの抽出, 精製に関する研究, 第 41 回日本 癌学会総会記事, $1252,1982$.

15）相良憲幸：ヒト肺癌細胞由来の癌胎児性抗原 の分離，精製に関する研究，日本臨床免疫学会 雑誌。(投稿中)

16) 原 満, 渡辺信一郎: 癌胎児性抗原 (Carcinoembryonic Antigen)の抗血清の特異性,医学の あゆみ，89，366-367, 1974.

17) Avrameas, S., Ternynck, T.: The crosslinking of proteins with glutaraldehyde and its use the preparation of immunoadsorbents, Immunochemistry, 6, 53-66, 1969.

18) Davis, B.J. : Disc electrophoresis- . Methods and application to human serum proteins, Ann. New York Acad. Sci., 121, 404-427, 1964.

19) Braatz, J.A., McIntire, K.R.: A rapid and efficient methods for the isolation of proteins 
from polyacrylamide gel, Preparative Biochemistry, 7,495-509, 1977.

20) Kuroki, M., Shinoda, T., Matuoka, Y. et al : Immunological characterization and structural studies of normal fecal antigen-1 related to Carcinoembryonic Antigen, Molec. Immunol., 19, 399-406, 1982.

21) Kuroki, M., Koga, Y., Matuoka, Y.: Purification and characterization of Carcinoembryonic Antigen-related antigens in normal adult feces, Cancer Res., 41, 713-720, 1981.

22) Matuoka,Y., Kuroki, M., Koga,Y. et al : Immunological differences among Carcinoembryonic Antigen in tumor tissues and related antigens in meconium and abult feces, Cancer Res., 42, 2012-2018, 1982.

23）一木貞徳, 黒木政秀, 黒木 求, 他: 膵癌由来株 化培養細胞(QGP-1)によるCarcinoembryonic Antigen(CEA)及げNonspecific cross-reacting antigen (NCA)の同時産生, 第40回日本癌学会 総会記事, 524, 1981.

24）福原 毅：ヒ卜消化器癌におけるCarcinoembryonic Antigen(CEA) の研究, 金沢大学十全医 学会雑誌，88，867-881， 1979.
25) Accolla, R.S. : Monoclonal antibodies specific for Carcinoembryonic Antigen and produced by two hybrid cell line, Proc. Natl. Acad. Sci. USA., 77, 563-566, 1980.

26) Mitchell, K.F.: A Carcinoembryonic Antigen(CEA) specific monoclonal hybridma antibody that reacts only with high-molecular-weight CEA, Cancer Immunol. Immunother., 10, 1-5, 1980.

27) Plow, E.F., Edgington, T.S.: Isolation and characterization of a homogenous isometric species of Carcinoembryonic Antigen : CEAS, Int, J. Cancer., 15, 748-761, 1975.

28) Rule, A.H., Goleski-Reilly, C.: Phasespecific oncocolon antigens. A theoretical framework for Carcinoembryonic Antigen specificities, Cancer Res., 34, 2083-2087, 1974.

29）一木貞德, 黒木政秀, 黒木 求, 他: 各種七卜 樹立癌細胞により産生されたCEAおよびNCA の免疫化学的比較解析, 第42回日本癌学会総会 記事，523， 1983.

30）今井浩三, 川原田信, 谷内 昭：モノクロー ナル抗体により明らかにされた分子及び抗原 決定基の多様性に関する研究，第13回日本免疫 学会総会記録，108, 1983. 


\title{
Isolation, Immunological Characterization and Chemical Analysis of CEA Found in a Lung Cancer Cell Line, HLC-1
}

\author{
Noriyuki Sagara \\ First Department of Surgery, Kinki University School of Medicine, \\ 380 Nishiyama, Sayama-cho, Osaka, Japan
}

CEA was first reported in 1965 as a colon cancer-specific antigen by Gold \& Freedman. However a number of studies thereafter have revealed that CEA exists not only in malignant tumors and that there are partly crossreacting substances in the normal lung, spleen, feces, and meconium, as well.

Burtin, von Kleist, and Matsuoka immunochemically analyzed CEA and these CEA analogues in normal tissues, and tried to differentiate CEA specific antigen determinant from others.

Although attention has been paid to the possible existence of some CEA with organ specificity, a lack of appropriate specimens, except for metastatic liver foci of colon cancers, has hampered further studies. The author tried to separate and purify CEA from a human lung cancer cell line (HLC-1) which secretes a large amount of substances with CEA activity into culture media.

CEA from HLC-1 [HLC-1 (CEA)] showed a fused precipitin line between colon cancer CEA but did not crossreact with NCA-1, NCA-2. The physicochemical properties of HLC-1 (CEA) were similar to colon cancer CEA in terms of amino acid composition, but differed in molecular weight $\left(\mathrm{HLC}-1(\mathrm{CEA})=27 \times 10^{4}\right.$ daltons $), \mathrm{pI}(\mathrm{HLC}-1(\mathrm{CEA})=4.4)$ and monosaccharide analysis (sialic acid was not detected).

HLC-1 (CEA) showed uniform physicochemical properties as did CEA-S, pH3/CEA, and is probably related to lung cancer-specific CEA. 